\begin{tabular}{cc|c}
\hline Tar. Bil. Der. & Tarm Bilimleri Dergisi & Journal of Agricultural Sciences \\
& $\begin{array}{c}\text { Dergi web sayfası: } \\
\text { www.agri.ankara.edu.tr/dergi }\end{array}$ & Journal homepage: \\
& www.agri.ankara.edu.tr/journal
\end{tabular}

\title{
Polymorphisms of TLR1, TLR4 and SLC11A1 Genes in Some Cattle Breeds Reared in Turkey
}

\author{
Korhan ARSLAN ${ }^{a}$, Bilal AKYÜZ ${ }^{\text {a }}$, Esma Gamze AKSEL ${ }^{\text {a }}$, Fadime ÖZDEMİR ${ }^{\mathrm{a}}$, Mehmet Ulaş ÇINAR \\ ${ }^{a}$ Erciyes University, Faculty of Veterinary Medicine, Department of Genetic, 38039, KAYSERI

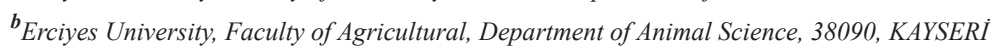

\section{ARTICLE INFO}

Research Article

DOI: $10.15832 /$ ankutbd.349728

Corresponding Author: Korhan ARSLAN, E-mail: korhanars@gmail.com, Tel: +90 (352) 2076666

Received: 07 November 2017, Received in Revised Form: 28 December 2017, Accepted: 12 January 2018

\begin{abstract}
The objective of this study was to examine the allelic and genotypic profiles of four SNPs of bovine Toll-Like receptor 1 (TLR1), Toll-Like Receptor 4 (TLR4) and Solute Linkete Carier 11A1 (SLC11A1) genes in Holstein, two Turkish native breeds and their crossbreds in Turkey. For this purpose, a total of 1023 cattle from Holstein (HL, $n=410$ ), Anatolian Black (AB, $n=106)$, East Anatolian Red (EAR, $n=84)$, Anatolian Black Crossbreed (ABC, $n=124)$ and East Anatolian Red crossbreed (EARC, $n=299$ ) breeds were examined for four SNPs. Samples were genotyped using by the PCR-RFLP method. According to the TLR1 (+1380) SNP, EAR was in Hardy-Weinberg equilibrium (HWE) while the AB, HL and native crossbreeds were deviated from HWE. All cattle breeds were in HWE for the TLR1 $(+1596)$ SNP. In terms of TLR4 (+10) SNP, the CC genotype had the highest frequency in HL and native crossbreeds whereas the AB and EAR breeds were monomorphic and only CC genotype was found these breeds. According to the SLC11A1 (+1066) SNP, the $\mathrm{CC}$ genotype had the highest while the GG genotype frequency the lowest in all breeds. In addition EAR breed was in HWE while the AB, HL and native crossbreeds deviated from HWE.
\end{abstract}

Keywords: Polymorphism; Turkish native cattle; Toll-Like Receptor; SLC11A1; Marker-assisted selection

\section{Introduction}

The immunity is divided into two namely the innate and adaptive immunity, in mammals. Innate immunity is present both in vertebrates and invertebrates, whereas adaptive immunity is only present in vertebrates (Takeda \& Akira 2001). Host genetic resistance is mainly sustained by innate immunity, providing protection against pathogens without being vaccinated or exposed to diseases (Prakash et al 2014). Deciphering host genotypes for disease resistance can help us to control livestock diseases and develop strategies for decreased economic losses in farm animal breeding.

TLR1 is associated with immune responses against many bacterial pathogens. It includes a TLR subfamily which creates heterodimers with TLR2. The resulting TLR1/TLR2 complex recognises different bacterial cell wall ingredients such as lipoproteins and lipopolysaccharides, thus mediating a natural immune response against Gram-positive and Gram-negative bacteria species (BuwittBeckmann et al 2006; Russell et al 2012). In this way, 
TLR1/TLR2 heterodimers and also TLR4 recognise mycobacterium Pathogen-Associated Molecular Patterns (PAMPs), then macrophages and dendritic cells are activated for immune response (Brightbill et al 1999; Chang et al 2006; Hawn et al 2007). It was reported that some mutations in the TLR1 and TLR4 genes decrease immune response against lipopeptide and lipopolysaccharide bacterial cell wall components (Hawn et al 2007). TLR4 plays on important role in immune response against both Gram negative and positive bacteria (Underhill et al 1999). Additionally, the TLR4 gene was reported to be a strong candidate gene for disease resistancy, such as against mastitis (Ogorevc et al 2009), paratuberculosis (Mucha et al 2009), and brucellosis (Prakash et al 2014).

Solute Linkete Carier 11A1 (SLC11A1) is a transmembrane protein and was reported to be one of the best known potential candidate genes that promote innate immunity against different intracellular pathogens (Kumar et al 2011). Therefore, the SCL11A1 gene variants may be used to nature resistance or susceptibility to some important infections such as tuberculosis in water buffalo (Le Roex et al 2013) and brucellosis in cattle (Kumar et al 2011; Prakash et al 2014).

The present study was aimed at determining the allele and genotype frequency of four SNPs of bovine TLR1, TLR4 and SLC11A1 genes in Holstein, Anatolian Black (AB), East Anatolian Red (EAR) cattle breeds and their crossbreeds in Turkey.

\section{Material and Methods}

A total of 1023 cattle made up of the Holstein ( $n=$ 410, from Kayseri, Kahramanmaraş, Balıkesir, Burdur, İzmir and Çanakkale), $\mathrm{AB}(\mathrm{n}=106$, from Kayseri, Sivas, Ankara, Çankırı, Niğde and Yozgat), EAR ( $\mathrm{n}=84$, from Erzurum, Kars and Ardahan), Anatolian Black crossbreed (ABC, $n=124$ from Kayseri, Sivas, Çorum, Niğde and Yozgat) and East Anatolian Red crossbreed (EARC, $n=299$, from Erzurum, Kars, Ardahan, Kayseri, Sivas, Çorum, Niğde and Yozgat) cattle were examined for four SNPs in the TLR1 $(+1380,+1596), T L R 4$ $(+10)$ and SLC11A1 $(+1060)$ genes. Genomic DNA was isolated from whole blood samples using the phenol-chloroform method (Sambrook et al 1989). Genotyping of TLR1, TLR4, TLR9 and SLC11A1 gene polymorphisms was performed by PCRRFLP. Detailed information about the primers, amplification product lengths and enzymes are used shown in Table 1.

The PCR for all SNPs was performed in $20 \mu \mathrm{L}$ reaction mixture, which included $1.5 \mathrm{mM} \mathrm{MgCl}_{2}$, $200 \mu \mathrm{M}$ dNTPs, $200 \mu \mathrm{M}$ primer, $1 \times$ PCR buffer, $1 \mathrm{U}$ Taq polymerase and 50-10 ng genomic DNA. The thermal cycling condition consisted of predenaturation $\left(94^{\circ} \mathrm{C}\right.$ for $\left.5 \mathrm{~min}\right)$ followed by 35 cycles of $30 \mathrm{~s}$ at $94{ }^{\circ} \mathrm{C}, 30 \mathrm{~s}$ at the annealing temperature (Table 1), $30 \mathrm{~s}$ at $72{ }^{\circ} \mathrm{C}$, and a final extension of 1 min at $72{ }^{\circ} \mathrm{C}$. For RFLP, each of the PCR products was digested with the appropriate enzyme (Table 1)

Table 1- Primer sequences, amplification conditions, product sizes and restriction enzymes

\begin{tabular}{|c|c|c|c|c|c|c|}
\hline$S N P$ & Primer sequence & $\begin{array}{l}A T \\
\left({ }^{\circ} \mathrm{C}\right)\end{array}$ & $\begin{array}{l}P S \\
(b p)\end{array}$ & $R E$ & $\begin{array}{l}R E \\
\text { Heat, inactivation temparatrures } \\
\text { and times }\end{array}$ & Reference \\
\hline $\begin{array}{l}\text { TLR1 } \\
(+1380)\end{array}$ & $\begin{array}{l}\text { F: 5'-TTTAGCAGCCTTTCCATACT-3', } \\
\text { R: 5'-TCTACCACGTCACTGGATACT-3' }\end{array}$ & 55 & 179 & $B s 1 \mathrm{I}$ & $\begin{array}{l}\text { Activation: } 55^{\circ} \mathrm{C} \text { for } 4 \text { hours } \\
\text { Inactivation: } 80^{\circ} \mathrm{C} \text { for } 20 \text { minutes }\end{array}$ & $\begin{array}{l}\text { Prakash et al } \\
2014\end{array}$ \\
\hline $\begin{array}{l}\text { TLR1 } \\
(+1596)\end{array}$ & $\begin{array}{l}\text { F: 5'-TTTAGCAGCCTTTCCATACT-3' } \\
\text { R: 5'-CAGATCCAGGTAGATACAGAG-3' }\end{array}$ & 64 & 354 & $B c l I$ & $\begin{array}{l}\text { Activation: } 55^{\circ} \mathrm{C} \text { for } 4 \text { hours } \\
\text { Inactivation: } 80^{\circ} \mathrm{C} \text { for } 20 \text { minutes }\end{array}$ & $\begin{array}{l}\text { Sun et al } \\
2012\end{array}$ \\
\hline $\begin{array}{l}\text { TLR4 } \\
(+10)\end{array}$ & $\begin{array}{l}\text { 5'-CGTAACCCAGCACTGCTTTG-3' } \\
\text { R: 5'-GCCTGTTAATGCCCTGTAACC-3 }\end{array}$ & 59.2 & 405 & BstUI & $\begin{array}{l}\text { Activation: } 37^{\circ} \mathrm{C} \text { for } 4 \text { hours } \\
\text { Inactivation: } 65^{\circ} \mathrm{C} \text { for } 20 \text { minutes }\end{array}$ & $\begin{array}{l}\text { Prakash et al } \\
2014\end{array}$ \\
\hline $\begin{array}{l}\text { SLC11A1 } \\
(+1066)\end{array}$ & $\begin{array}{l}\text { F: 5'-ATCTCCTTCCTACTGCCCG-3' } \\
\text { R: 5'-CACAAACTGTCCCGCGTAG-3' }\end{array}$ & 54 & 374 & Pst I & $\begin{array}{l}\text { Activation: } 37^{\circ} \mathrm{C} \text { for } 15 \text { minutes } \\
\text { Inactivation: } 80^{\circ} \mathrm{C} \text { for } 20 \text { minutes }\end{array}$ & $\begin{array}{l}\text { Prakash et al } \\
2014\end{array}$ \\
\hline
\end{tabular}

AT, annealing temperature; PS, product size; RE, restriction enzyme 
in a reaction including $3 \mu \mathrm{L}$ of the PCR product, 5 $\mathrm{U}$ of the restriction enzyme (MBI Fermentas) and 1 $\mu \mathrm{L}$ of the buffer. The reaction was incubated at the appropriate temperature for each enzyme (Table 1) for $4 \mathrm{~h}$. Genotyping for each SNP was performed by $3 \%$ agarose gel electrophoresis.

The genotype and allele frequencies of the examined SNPs in each breed were calculated. The Hardy-Weinberg equilibriums (HWE) of the examined breeds for five SNPs in the TLR1, TLR4 and SLC11A1 genes were analysed using the Chisquare test. All statistical analyses were made by using FSTAT v.2.9.3.2 software.

\section{Results and Discussion}

After digestion with the $B S 1$ I restriction enzyme digestion, the AA (179 bp), AG (179, 93 and 86 bp) and GG (93 and 86 bp) genotypes were observed for the TLR1 $(+1380)$ SNP (Figure 1). The 93 and 86 bp bands were not separated because of their close proximity to each other. However, genotypes could be detected by observing one or two fragments of 179 and around $100 \mathrm{bp}$. The AG genotype had the highest frequency while the AA genotype frequency had the lowest in all examined breeds. According to the TLR1 $(+1380)$ SNP, EAR breed was in HWE while the $\mathrm{AB}, \mathrm{HL}$ and native crossbreeds deviated from HWE (Table 2).

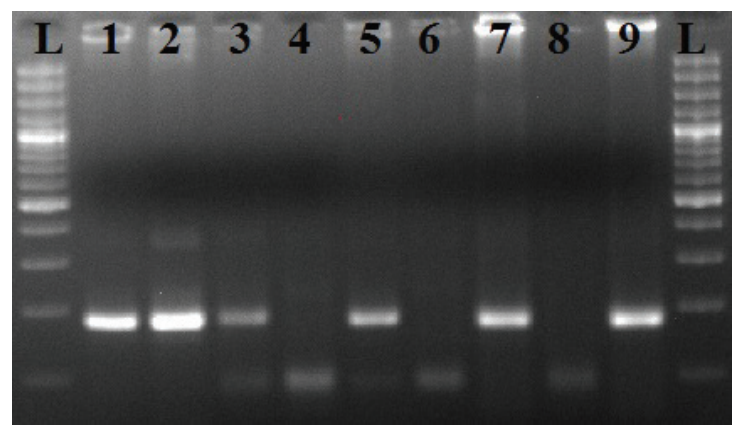

Figure 1- Picture of restriction fragments of TLR1 $(+1380)$ locus after digestion with $B s 1 \mathrm{I}$ restriction enzyme Lane $L$, markers (100 bp); lanes 1, 2, 7 and 9, AA genotypes; lanes 3 and 5, AG genotypes; lanes 4,6 and 8, GG genotypes
As a result of restriction enzyme digestion, three genotypes for the TLR1 $(+1596)$ polymorphism were detected: 261, 72 and $21 \mathrm{bp}$ for the GG genotype; 333, 261, 72 and $21 \mathrm{bp}$ for the GH genotype; 333 and $21 \mathrm{bp}$ for the HH genotype (Figure 2). The GH genotype had the highest frequency in all breeds followed by $\mathrm{HH}$ and $\mathrm{GG}$, respectively, in all examined breeds except for EAR in which $\mathrm{HH}$ was found as the most frequent genotype compared to GH. All cattle breeds were in HWE for this SNP (Table 2).

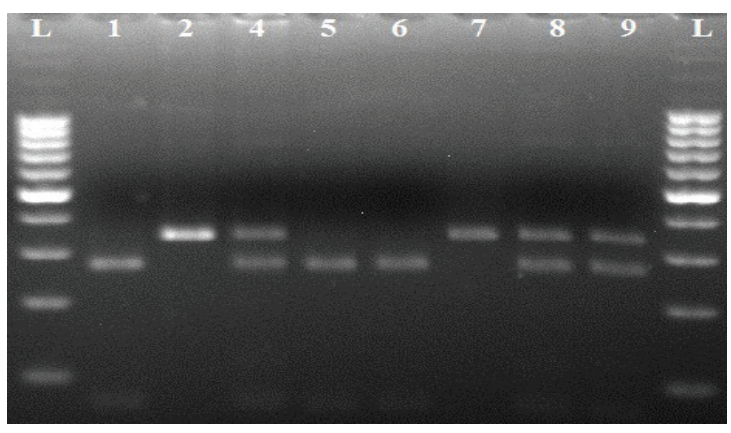

Figure 2- Picture of restriction fragments of $T L R 1$ $(+1596)$ locus after digestion with $B c l I$ restriction enzyme Lane $L$, markers (100 bp); lanes 1, 5 and 6, GG genotypes; lanes 2 and 7, HH genotypes; lanes 4,8 and 9, GH genotypes

Following digestion with Bst UI enzyme for the TLR4 $(+10)$ SNP, in the CC genotype two bands with a length of 246 and $159 \mathrm{bp}$, and in the CT genotype three bands with a length of 405, 246 and $159 \mathrm{bp}$ were observed (Figure 3). However, the TT genotype was not observed (Figure 3 ). The genotype $\mathrm{CC}$ had the highest frequency in HL and native crossbreeds whereas the monomorphic genotype was found in $\mathrm{AB}$ and EAR breeds (Table 2).

The polymorphism in the SLC11A1 $(+1066)$ mutation was identified by digestion of the PCR product with Pst $\mathrm{I}$ enzyme. In this study, three genotypes were obtained for the SLC11A1 (+1066) SNP (CC, CG and GG) in the examined cattle breeds. After digestion with PstI, one fragment was observed for the CC genotype (348 and 95 bp), two fragments were observed for the GG genotype (293 and $81 \mathrm{bp}$ ) and three fragments were found expected 


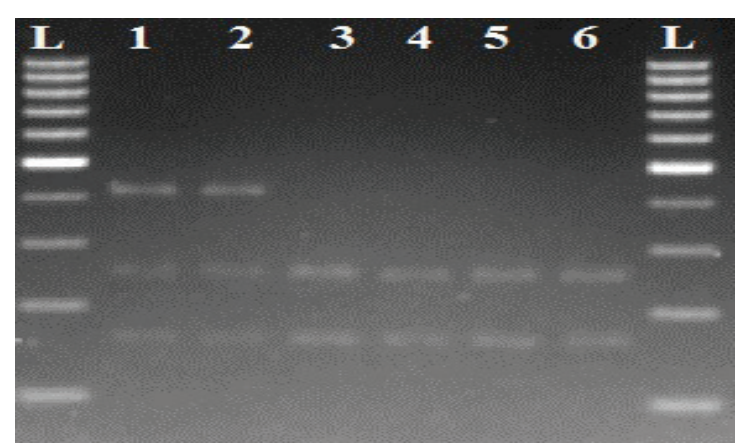

Figure 3- Picture of restriction fragments of TLR4 $(+10)$ locus after digestion with $B s t U I$ restriction enzyme Lane $L$, markers (100 bp); lanes 1 and 2, CT genotypes; lanes 3, 4, 5 and 6, $\mathrm{CC}$ genotypes for the $\mathrm{AB}$ genotype (374, 293 and $81 \mathrm{bp}$ ) (Figure 4). The $\mathrm{CC}$ genotype had the highest frequency while the GG genotype frequency was the lowest in all breeds. Turkish native cattle breeds were in HWE while HL and crossbreeds deviated from HWE (Table 2).

The observed heterozygosity varied from 0.284 to 0.568 for $T L R 1+1380$, from 0.401 to 0.502 for TLR1 +1596, from 0.000 to 0.018 for TLR4 +10 , and from to 0.168 to 0.370 for the SLC11A1 +1066 polymorphism in the five examined cattle populations. The expected heterozygosity, the observed heterozygosity, the allele and genotype

Table 2- Heterozygosity, allele and genotype frequencies of examined loci in cattle breed reared in Turkey

\begin{tabular}{|c|c|c|c|c|c|c|c|c|c|c|}
\hline \multirow{2}{*}{$S N P$} & \multirow{2}{*}{ Breed } & \multirow{2}{*}{$n$} & \multicolumn{2}{|c|}{ Allele frequency } & \multicolumn{3}{|c|}{ Genotype frequency } & \multicolumn{2}{|c|}{ Heterozygosity } & \multirow{2}{*}{$X^{2}(d f=1)$} \\
\hline & & & $A$ & $G$ & $A A$ & $A G$ & $G G$ & $H_{E}$ & $H_{O}$ & \\
\hline \multirow{5}{*}{ TLR1 (+1380) } & HL & 410 & 0.270 & 0.730 & 0.003 & 0.539 & 0.458 & 0.395 & 0.537 & $53.500 *$ \\
\hline & $\mathrm{AB}$ & 106 & 0.190 & 0.810 & 0.000 & 0.387 & 0.613 & 0.303 & 0.371 & $6.090 *$ \\
\hline & $\mathrm{ABC}$ & 124 & 0.270 & 0.730 & 0.008 & 0.524 & 0.468 & 0.395 & 0.524 & $13.440^{*}$ \\
\hline & EAR & 84 & 0.150 & 0.850 & 0.000 & 0.298 & 0.702 & 0.245 & 0.284 & $2.570^{\mathrm{NS}}$ \\
\hline & EARC & 299 & 0.290 & 0.710 & 0.003 & 0.569 & 0.428 & 0.410 & 0.568 & $44.880 *$ \\
\hline \multirow{6}{*}{ TLR1 (+1596) } & & & $\mathrm{G}$ & $\mathrm{H}$ & GG & $\mathrm{GH}$ & $\mathrm{HH}$ & & & \\
\hline & HL & 410 & 0.400 & 0.600 & 0.151 & 0.502 & 0.347 & 0.481 & 0.502 & $0.730^{\mathrm{NS}}$ \\
\hline & $\mathrm{AB}$ & 106 & 0.440 & 0.560 & 0.217 & 0.453 & 0.330 & 0.493 & 0.474 & $0.720^{\mathrm{NS}}$ \\
\hline & $\mathrm{ABC}$ & 124 & 0.420 & 0.580 & 0.210 & 0.427 & 0.363 & 0.490 & 0.427 & $1.930^{\mathrm{NS}}$ \\
\hline & EAR & 84 & 0.310 & 0.690 & 0.095 & 0.429 & 0.476 & 0.429 & 0.419 & $0.000^{\mathrm{NS}}$ \\
\hline & EARC & 299 & 0.460 & 0.540 & 0.258 & 0.401 & 0.341 & 0.497 & 0.401 & $10.980^{*}$ \\
\hline \multirow{6}{*}{ TLR4 (+10) } & & & $\mathrm{C}$ & $\mathrm{T}$ & $\mathrm{CC}$ & $\mathrm{CT}$ & $\mathrm{TT}$ & & & \\
\hline & HL & 410 & 0.998 & 0.002 & 0.995 & 0.005 & 0.000 & 0.002 & 0.004 & 0.000 \\
\hline & $\mathrm{AB}$ & 106 & 1.000 & 0.000 & 1.000 & 0.000 & 0.000 & 0.000 & 0.000 & 0.000 \\
\hline & $\mathrm{ABC}$ & 124 & 0.996 & 0.002 & 0.992 & 0.008 & 0.000 & 0.004 & 0.019 & 0.000 \\
\hline & EAR & 84 & 1.000 & 0.000 & 1.000 & 0.000 & 0.000 & 0.000 & 0.000 & 0.000 \\
\hline & EARC & 299 & 0.990 & 0.010 & 0.980 & 0.020 & 0.000 & 0.010 & 0.008 & $0.030^{\mathrm{NS}}$ \\
\hline \multirow{6}{*}{ SLC11A1 (+1066) } & & & $\mathrm{C}$ & G & $\mathrm{CC}$ & CG & GG & & & \\
\hline & HL & 410 & 0.850 & 0.150 & 0.763 & 0.171 & 0.066 & 0.254 & 0.168 & $45.990 *$ \\
\hline & $\mathrm{AB}$ & 106 & 0.850 & 0.150 & 0.755 & 0.189 & 0.056 & 0.262 & 0.206 & $7.380 *$ \\
\hline & $\mathrm{ABC}$ & 124 & 0.800 & 0.200 & 0.702 & 0.194 & 0.104 & 0.323 & 0.193 & $19.720^{*}$ \\
\hline & EAR & 84 & 0.760 & 0.240 & 0.570 & 0.370 & 0.060 & 0.374 & 0.370 & $0.000^{\mathrm{NS}}$ \\
\hline & EARC & 299 & 0.780 & 0.220 & 0.679 & 0.201 & 0.120 & 0.344 & 0.200 & $51.920 *$ \\
\hline
\end{tabular}

$\mathrm{H}_{\mathrm{E}}$, expected heterozygosity; $\mathrm{H}_{\mathrm{O}}$, observed heterozygosity; $\mathrm{X}^{2}$, Chi-square; HL, Holstein; $\mathrm{AB}$, Anatolian Black; EAR, East Anatolian Red; ABC, Anatolian Black Crossbreed; EARC, East Anatolian Red Crossbreed; df, freedom degree; *, statistical significance 0.05; NS, Non significant 


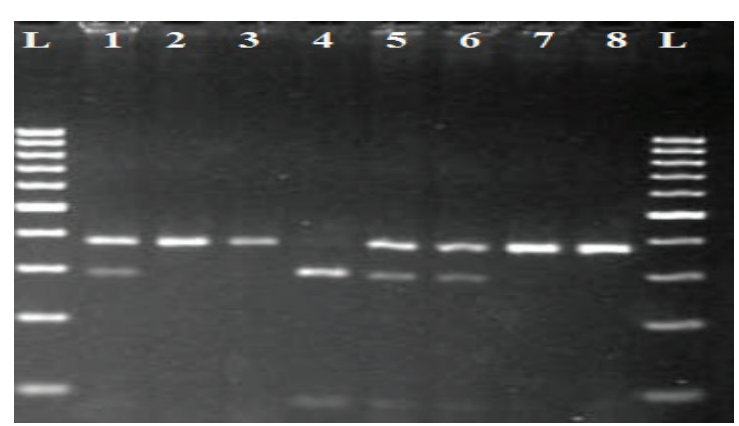

Figure 4- Picture of restriction fragments of SLC11A1 (+1066) locus after digestion with PstI restriction enzyme Lane $L$, markers (100 bp); lanes 1, 5 and 6, CG genotypes; lanes 2, 3, 7 and 8, CC genotypes; lane 4, GG genotype

frequencies for four polymorphism of the HL, AB, ABC, EAR, EARC populations are shown in Table 2.

Genomic and phenotypic selection for increasing milk yield have resulted in a decrease in the health traits of high yielding cattle breeds such as Holstein (Egger-Danner et al 2015). However, increasing milk production is no longer as important trait as it used to be, compared to health and longevity. In today's dairy cattle breeding, health and longevity are more important for selection than milk production (Egger-Danner et al 2015). The main goal of dairy cattle farming is to increase income by obtaining higher milk and meat yield and to lower the costs caused by lower fertility, high disease and culling rates (Strapáková et al 2016).

It has been shown that TLRs are associated with innate immune response in various livestock species (Le Roex et al 2013; Prakash et al 2014). Therefore, interest in breeding animals which are resistant to major infectious diseases by using TLRs genes has increased tremendously in recent years (Novák 2014).

The TLR1 (+1380) SNP was firstly reported by Prakash et al (2014) in Indian native cattle breeds and their crossbreeds and they observed three genotypes for the TLR1 $(+1380)$ locus. The AG genotype frequency was higher than other genotypes, and AA genotype frequency was found to be lower in Indian native cattle (Prakash et al 2014). In a study conducted in Turkey, five different cattle breeds had been genotyped with this SNP. According to this study, although the genotype GG was the most common genotype in all breeds genotyped, the AA genotype was not found among examined animals. (Çınar et al 2016). Similarly, in this study AA genotype was not found in $\mathrm{AB}$ and EAR breeds. The AA genotype was the lowest in Holstein and crossbreeds in our examined population (Table 2). However, in Turkish native cattle breeds (AB and EAR) no AA genotype was observed (Table 2 ). In the present study the $G$ allele was the most frequently found allele in all the examined breeds and the GG genotype was found to be higher in the investigated Turkish native cattle breeds (Table 2). In Holstein and crossbreeds, the frequencies of the genotype AG were found to be slightly higher compared to the GG genotype (Table 2). The TLR1 $(+1596)$ SNP was firstly reported in the Holstein breed (Sun et al 2012). The authors observed three genotypes ( $\mathrm{GG}, \mathrm{GH}$ and $\mathrm{HH}$ ) and the frequency of the GH genotype was found to the highest in the Holstein breed (Sun et al 2012). Similarly, we found three genotypes in all examined breeds, and the GH genotype frequency was the highest in Holstein, $\mathrm{AB}$ and crossbreeds, whereas the HH genotype was found to be highest in the EAR breed (Table 2). The TLR4 (+10) SNP was monomorphic in Turkish native cattle breeds; additionally, this SNP was almost monomorphic in Holsteins and crossbreeds (Table 2). Similarly, Bilgen et al (2016) reported low variation in the AB, EAR and Holstein breeds in terms of TLR4 SNP with. However, Prakash et al (2014) observed three genotypes (CC, CT and TT) for TLR4 $(+10)$ in Indian native cattle breeds. The SLC11A1 $(+1066)$ SNP was polymorphic in all examined breeds in the present study (Table 2). The frequency of the CC genotype was found to be the highest in the investigated animal populations. Prakash et al (2014) also observed three genotypes; however, in contrast to our study, the CC genotype was the least common in Indian native cattle.

Three of the SNPs genotyped [TLR1 $(+1380)$, TLR4 $(+10)$ and SLC11A1 (+1066)] in this study were taken from a study that investigates Bos indicus cattle 
derived by Prakash et al (2014). There they reported that samples, they examined were polymorphic and found in HWE. In contrast, in our study, Bos taurus origin cattle were used and in terms of these SNPs, deviation from HWE was observed in all breeds except EAR (Table 2). It is thought that this may have been due to the origins of examined cattle breeds (Lin et al 2010). In the light of those findings, it was observed that examined all breeds were in HWEs in terms of TLR1 (+1596) SNP. HWE was not observed just in breed of EARC (Table 2).

This study is the first to investigate the genotype and allele frequencies of TLR1 $(+1380,+1596)$, TLR4 $(+10)$ and SLC11A1 $(+1066)$ SNPs in cattle breeds reared in Turkey. The present study indicated that among the investigated SNPs, heterozygosity was detected as $<0.5$, which shows low variation for these SNPs (Table 2). Prakash et al (2014) reported an association between the TLRI $(+1380) \mathrm{AA}, T L R 4$ $(+10)$ TT and SLC11A1 $(+1060)$ CC genotypes and resistance to bovine brucellosis. In addition, Sun et al (2012) found an association between the TLR1 $(+1596)$ GG genotype and resistance to bovine tuberculosis. According to the findings of Prakash et al (2014) and Sun et al (2012), we hypothesise that our investigated populations in Turkey had a greater relative risk of incidence to bovine brucellosis and tuberculosis. This is because, the genotypes given by Prakash et al (2014) as indicating susceptibility to bovine brucellosis and tuberculosis were found to have a higher frequency in our examined populations, except for SLC11A1 (+1066).

Prakash et al (2014) reported that the SNPs used in this study might be used in genomic selection against bovine brucellosis and tuberculosis. In conclusion, increasing the frequencies of the TLR1 $(+1380-A$, $+1596-G)$ and TLR4 $(+10-T)$ alleles may help to control bovine brucellosis and tuberculosis infections in Turkey. Further studies which study the association between reported SNPs and bovine brucellosis and tuberculosis infections in Turkey are needed.

\section{Acknowledgements}

This study was supported by the Erciyes University Scientific Research Projects Unit, within the scope of the project with the number TCD-2014-5449.

\section{References}

Bilgen N, Cinar Kul B, Offord V, Werling D \& Ertugrul O (2016). Determination of genetic variations of TollLike Receptor (TLR) 2, 4, and 6 with next-generation sequencing in native Cattle breeds of Anatolia and Holstein Friesian. Diversity 8(4): 23

Brightbill H D, Libraty D H, Krutzik S R, Yang R B, Belisle J T, Bleharski J R, Maitland M, Norgard M V, Plevy S E, Smale S T, Patrick J B, Barry R B, Paul J G \& Robert L M (1999). Host defense mechanisms triggered by microbial lipoproteins through Toll-Like Receptors. Science 285: 732-736

Buwitt-Beckmann U, Heine H, Wiesmuller K H, Jung G, Brock R, Akira S \& Ulmer A J (2006). TLR1and TLR6-independent recognition of bacterial lipopeptides. The Journal of Biological Chemistry 281: 9049-9057

Chang J S, Huggett J F, Dheda K, Kim L U, Zumla A \& Rook G A (2006). Myobacterium tuberculosis induces selective up-regulation of $\mathrm{Tl}+\mathrm{rs}$ in the mononuclear leukocytes of patients with active pulmonary tuberculosis. The Journal of Immunology 176: 30103018

Çınar M U, Arslan K, Ilgar E G \& Akyüz B (2016). Determination of Toll-Like Receptor 1 Gene polymorphisms in Zavot, Turkish Grey, East Anatolian Red, Anatolian Black and South Anatolian Red Cattle Breeds. Turkish Journal of Agriculture-Food Science and Technology 4(5): 352-355

Egger-Danner C, Cole J B, Pryce J E, Gengler N, Heringstad B, Bradley A \& Stock K F (2015). Invited review: overview of new traits and phenotyping strategies in dairy cattle with a focus on functional traits. Animal 9(2): 191-207

Hawn T R, Misch E A, Dunstan S J, Thwaites G E, Lan N T, Quy H T, Chau T T, Rodrigues S, Nachman A, Janer M, Hien T T, Farrar J J \& Aderem A (2007). A common human Tlr1 polymorphism regulates the innate immune response to lipopeptides. European Journal of Immunology 37: 2280-2289

Kumar N, Ganguly I, Singh R, Deb S M, Kumar S, Sharma A \& Mitra A (2011). Dna polymorphism in 
Slc11a1 Gene and its association with Brucellosis resistance in Indian Zebu (Bos Indicus) and crossbred (Bos Indicus $\times$ Bos Taurus) Cattle. Asian-Australasian Journal of Animal Sciences 24(7): 898-904

Le Roex N, Koets A P, Van Helden P D \& Hoa E G (2013). Gene polymorphisms in African Buffalo associated with susceptibility to bovine tuberculosis infection. Plos One 8(5): E64494

Lin B Z, Sasazaki S \& Mannen H (2010). Genetic diversity and structure in Bos taurus and Bos indicus populations analyzed by SNP markers. Animal Science Journal 81: 281-289

Mucha R, Bhide M R, Chakurkar E B, Novak M \& Mikula S R I (2009). Toll-Like receptors Tlr1, Tlr2 and Tlr4 Gene Mutations and natural resistance to Mycobacterium Avium Subsp. Paratuberculosis infection in Cattle. Veterinary Immunology and Immunopathology 128: 381-388

Novák K (2014). Functional polymorphisms in Toll-Like receptor Genes for innate immunity in farm animals. Veterinary Immunology and Immunopathology 157(1): 1-11

Ogorevc J, Kunej T, Razpet A \& Dovc P (2009). Database of cattle candidate Genes and genetic markers for milk production and mastitis. Animal Genetics 40: 832-851

Prakash O, Kumar A, Sonwane A, Rathore R, Singh R V, Chauhan A, Kumar P, Renjith R, Yadav R, Bhaladhare A, Baqir M \& Sharma D (2014). Polymorphism of cytokine and innate immunity genes associated with bovine brucellosis in cattle. Molecular Biology Reports 41: 2815-2825

Russell C D, Widdison S, Leigh J A \& Coffey T J (2012). Identification of single Nucleotide polymorphisms in the Bovine Toll-Like Receptor 1 Gene and association with health traits in Cattle. Veterinary Research 43(1): 17

Sambrook J, Fritsch E F \& Maniatis T (1989). Molecular Cloning: A Laboratory Manual ( $\left.2^{\text {nd }} E d.\right)$, Cold/Spring Harbor, New York

Strapáková E, Candrák J \& Strapák P (2016). Genetic relationship of lactation persistency with milk yield, somatic cell score, reproductive traits, and longevity in Slovak Holstein Cattle. Archives Animal Breeding 59: 329-335

Sun L, Song Y, Riaz H, Yang H, Hua G, Guo A \& Yang L (2012). Polymorphisms in Toll-Like receptor 1 and 9 genes and their association with tuberculosis susceptibility in Chinese Holstein Cattle. Veterinary Immunology and Immunopathology 147: 195-201

Takeda K \& Akira S (2001). Roles of Toll-Like receptors in innate immune responses. Genes Cells 6: 733-742

Underhill D M, Ozinsky A, Smith K D \& Aderem A (1999). Toll-Like receptor-2 mediates mycobacteriainduced proinflammatory signaling in macrophages. Proceedings of the National Academy of Sciences 96: 14459-14463 